\title{
コンクリート中鋼材の塩化物窝食調査 及び試験方法
}

宮 川豊 章*1・片 脇 清*2

1.はじめに

コンクリート構造物の耐久性（本稿では特に塩化物腐 食）を検討しようとする場合，その対象となる期間は， 構造物が施工されてから維持・補修を経て解体するまで である。従って, 対象構造物が要求される性能を現実に どの程度満足させているかを調查検討し，その維持を図 ることが極めて重要である。

しかし，現在種々報告されている塩化物腐食を生じた 構造物の調査方法は, その調查管理体制を含めてまだ確 立されたものはない。また, 現実の塩化物腐食の問題を 定性あるいは定量的に検討するにあたって必要な, 室内 における試験方法も様々な方法がとられているのが現状 である。

本稿は, 実在構造物における調査において用いられる 一般的な手順及び室内試験方法をとりまとめ, その特徵 を簡単に示すものである。

\section{2. 実在構造物の腐食調査}

実在する構造物の腐食調查を行うにあたっては, 腐食 に関する種々の情報を収集することが, 現実の腐食機構 及び要因, 更には腐食状態を推定するために必要であ る。そのため, 種々の項目に関して調查を行うことが望 ましい。

一般には以下の項目を挙げることができるが, 構造物 の劣化度を知り, 補修の時期 - 方法を検討する場合に は, 必要に応じて組み合わせた調査を行えばよい。

\section{1 外観 調 查}

まず, 対象構造物の環境, 立地条件を調べる。海中,

*1 正会員 京都大学助手 工学部土木工学科

*2 正会員 建設省土木研究所地質化学部主任研究員
飛沫帯, 海上大気中の区別, あるいは凍結融解の可能 性, 季節風などの環境条件, また電カプラントなどから の迷走電流の有無などの立地条件を調べ，構造物がどの ような状態に置かれているかを確認した後に構造物その ものの調查を始める。

コンクリートの劣化程度, 剝離, ひびわれ, 更に錆汁 のにじみ出た部分や変色部分を記録する。ひびわれに関 する調查方法の詳細は, 文献 1)，2）等を参考にされた い。

\section{2 配 筋 状 態}

鉄筋探査器により，鉄筋位置及びかぶり厚さを確認す る。できれば配筋図と比較することが望ましい。

\section{3 鉄筋の自然電位測定 ${ }^{3), 4)}$}

かぶりコンクリートをはつり取らずに鉄筋の腐食状態 を調査する有力な手法として, 自然電位分布の測定があ る。

電位測定は図一1 のような方法で行われる。参照電極

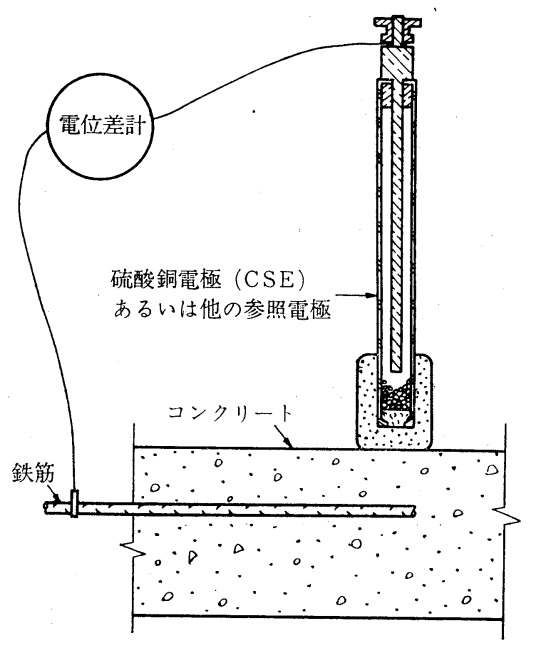

図一1 自然電位測定概要 


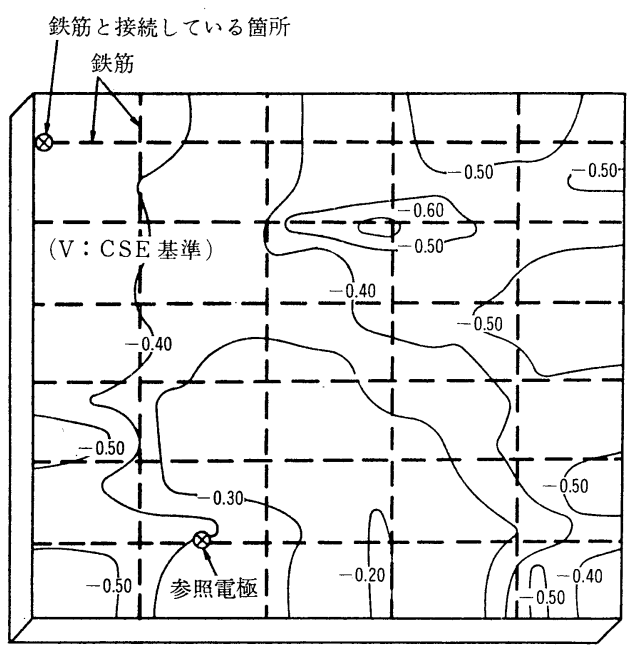

図一2 等電位線図

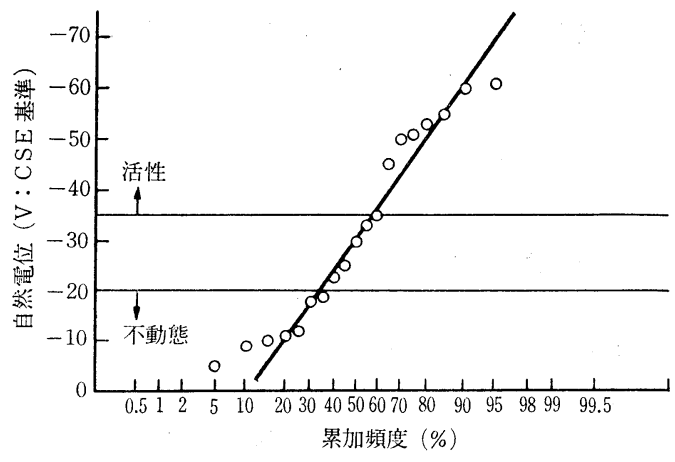

図一3 累加頻度図

としては, 硫酸銅電極 (CSE) が用いられる場合が多い が，塩化銀，飽和カロメル（SCE）等の電極を用いても よい。電位差計としては入力抵抗 $10^{7} \Omega$ 以上, 最小目 盛 $20 \mathrm{mV}$ 以下のものを用い, $10 \mathrm{mV}$ 単位以下 で測定 する。測定間隔は通常 $1 \mathrm{~m}$ 程度以下とし, 最大の電位 変化が $100 \mathrm{mV}$ 以下となるようにする。

測定にはコンクリートの含水量が大きな影響を与え る。測定值が変化したり，ふらついたりする場合には， あらかじめコンクリート表面全体あるいは測定点をぬら すか，ぬらしたスポンジを測定点に置き，5分以上一定 值が得られるようにする。ただし, 測定点の間はぬれて いてはならない。また，海中などの水中においては，電 位が全体として一定の值となって得られるため, 電位の 分布を得ることは困難である。

測定結果は, 等電位線図 (図一2), 西るいは累加頻度 図（図一3）等によって整理される。

ASTM によれば, 電位 $E$ (V vs CSE) が測定され たその箇所での鉄笳の腐食状態は, 次のような状態にあ る。

Vol. 19, No. 3, March 1981

$$
\begin{array}{rl}
-0.20<E & 90 \% \text { 以上の確率で腐食が生じ } \\
-0.35<E \leq-0.20 & \text { ていない。 } \\
E<-0.35 & \text { 不確定。 } \\
& 90 \% \text { 以上の確率で腐食が生じ } \\
& \text { ている。 }
\end{array}
$$

もし電位として正の值が得られる場合には，コンク リートに十分な水分が含まれておらず，信頼すべき 値とは見なせない。

\section{4 コンクリート中の塩化物量}

コンクリート中の塩化物の挙動はよく知られておら ず，そのため種々の測定 法が提案されている。い ずれにしてもコンクリー 卜から塩化物を抽出する 必要があり，目的に応じ て, 例えば水溶性のもの だけか，あるいはセメン ト成分と結合したものま で測定するかで, 塩化物 の抽出方法を変える必要 がある。通常は, 腐食に 関係するのは固定化され ていない塩化物と考え, 前者が目的とされる5)。

この測定方法としては 再現性がよく, しかも比 較的簡便な方法として, ハンマードリル等により コンクリート粉を深さ方 向化採取し, 塩素イオン 電極によって電位差滴定 する方法がある6

塩化物量が $0.59 \mathrm{~kg} / \mathrm{m}^{3}$ 以上であれば, $95 \%$ の信 頼性をもって鉄筋が腐食

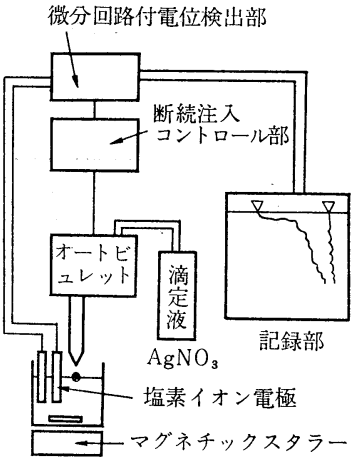

(a) 電位差滴定 $A$ 法

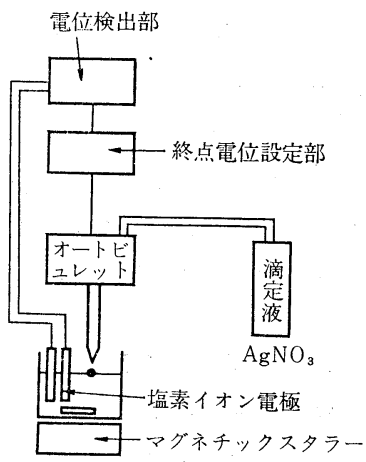

(b) 電位差滴定 $B$ 法

\section{図一4 電位差滴定法}

更に，全塩化物量の測定方法としては，希硝酸で分解 した後, チオシアン酸第 2 水銀を用いて行う吸光光度法 などがある゙

\section{5 中 性 化}

海洋環境などの塩分雰囲気中においては, 腐食の原因 が塩化物に起因することが多いため, 通常，コンクリー 卜の中性化はあまり重要ではない。しかし，コンクリー 卜の中性化が鉄筋に達すると鉄筋は腐食する ${ }^{9)}$ 考えら れているため, 鉄筋のかぶり厚さが小さな, 海上大気中 


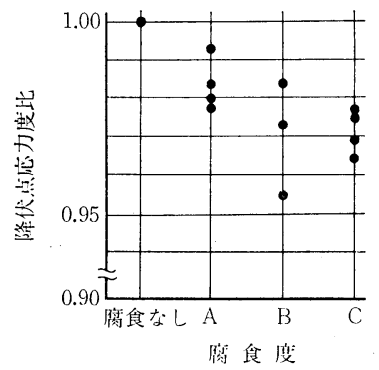

図一5＼cjkstart鉄筋の腐食度と降伏点応力度比の関係

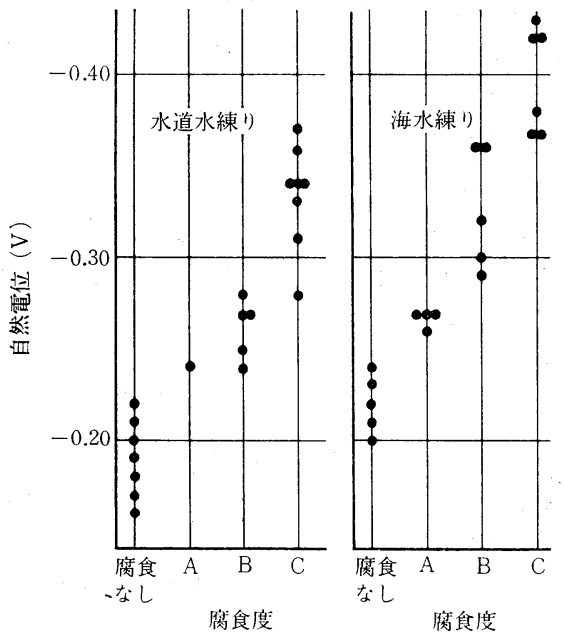

図一6 鉄筋の自然電位と腐食度の関係

の構造物では考虑する必要がある。

中性化深さの測定には，フェノールフタレインのエチ ルアルコール $1 \%$ 溶液を噴霧する方法がよい（チモー ルフタレインを用いた方がより安全側で測定することが できるが，変色を判別しにくい)。

\section{6 鉄筋の腐食度}

腐食調查で最も確実な方法は, 鉄筋位置までコンクリ 一トをはつりとって測定することである。露出させた鉄 筋は，腐食の程度に応じて何段階かのレベルに分類して 判定する場合が多い。例えば森らは ${ }^{10)}$ ，以下の 4 種に分

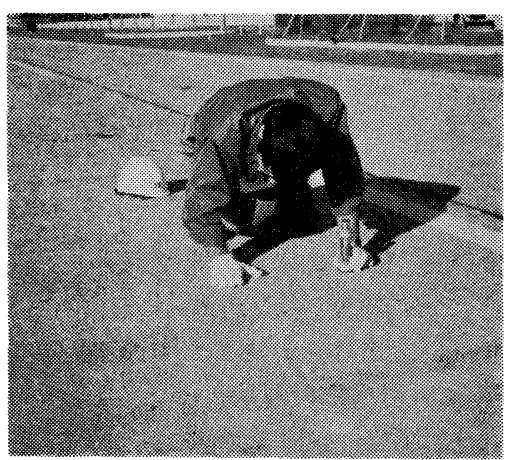

写真一1 コンクリート表面の劣化状態の観察

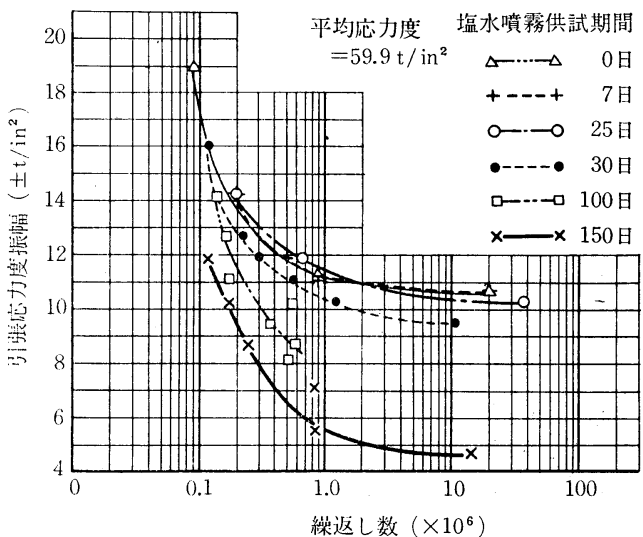

図一7塩水噴霧腐食後における疲労特性

類している。

腐食なし：腐食を認めず。

腐食度 A : ごく表面的な腐食。

腐食度 B：浅い孔食など断面欠損の軽微な腐食。

腐食度 C : 断面欠損の明らかな著しい腐食。

更に，以上のような分類は，図一5，6のように，鉄 筋の劣化及び自然電位と相関があると報告している。

\section{7 強度試験}

P C 鋼材における応力腐食割れ，水素脆性を除外すれ ば，鉄笳が強度減少を生ずるまでにかぶりコンクリート が剥離を生ずるため，少なくとも静的強度の減少はあま り問題とはならない。しかし，耐疲労特性には比較的大 きな影響を与えるとされている。

図一7 に示す結果 ${ }^{11)}$ では, 静的な強度の面ではあまり 差がないにもかかわらず，耐疲労特性は腐食程度によっ て比較的影響を受けることが明らかとなった。このた め, 部材をも含めて, 腐食劣化の程度を疲労試験により 定量化しようという試みも多い。

ここで，建設省土木研究所における鉄筋腐食調查の一 例を写真一1〜6 に示す。

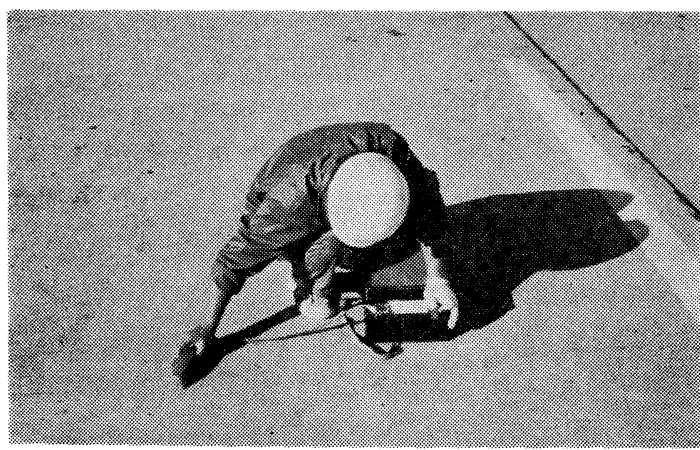

写真一2 鉄筋探查器による鉄筋位置及びかぶり厚さの測定 


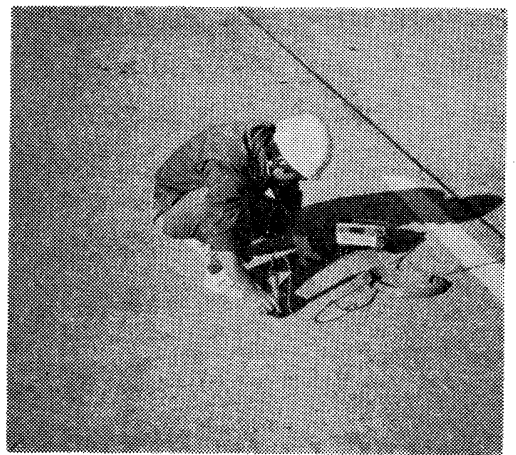

写真一3 鉄筋の自然電位分布の測定

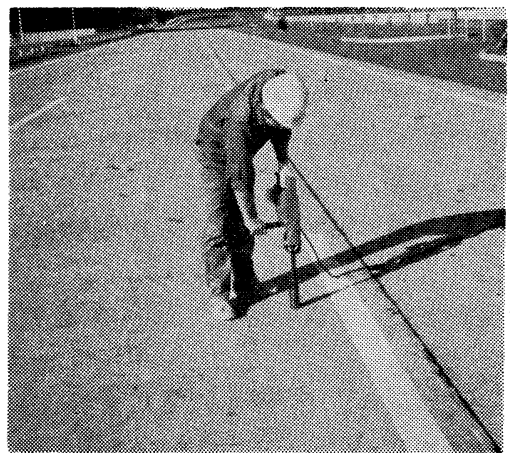

写真一5 電動ハンマードリルによる塩化物分析用 コンクリートサンプルの採取

\section{3．室内において用いられる試験方法}

実在の構造物における腐食機構は非常に多くの要因か ら成り立っているため, 調査結果を単純に一つの要因に よって説明することは不可能である。そのため, これら の要因のうち主要なものを取り出し，室内において試験 を行い, 取り出した要因がどのように腐食現象に対して 影響を与えるかを検討することが必要である。

室内試験においては，現実の構造物あるいは環境条件 等をそのまま用いることができないために，種々のモデ ル化が必要である。具体的には, 構造物のモデル化とし ては，形状寸法を小さくしたもの，目的とする具体的な 腐食機構を単純化したもの，コンクリート片に鋼材を埋 め込んだもの，コンクリート中液相のモデルとしての $\mathrm{Ca}$ 飽和水溶液の使用を挙げることができる。環境条件 のモデル化としては, 食塩水あるいは人工海水への浸 漬, 乾湿繰返し，気象条件をシミュレーションしたもの などを挙げることができる。これらのモデル化は，必ず その得られた值に限界があり，モデル化を誤れば現実と は全く異なった結果が得られる恐れがあるため，常にど のようにモデル化したかを念頭に置いておかなければな らない。

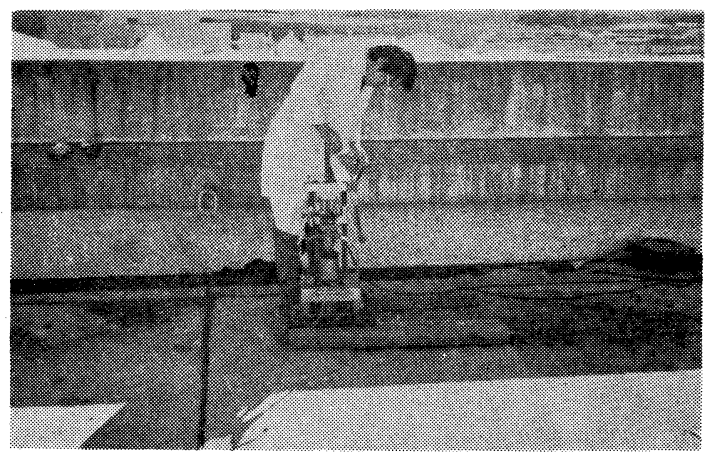

写真一4 コンクリートコアの採取

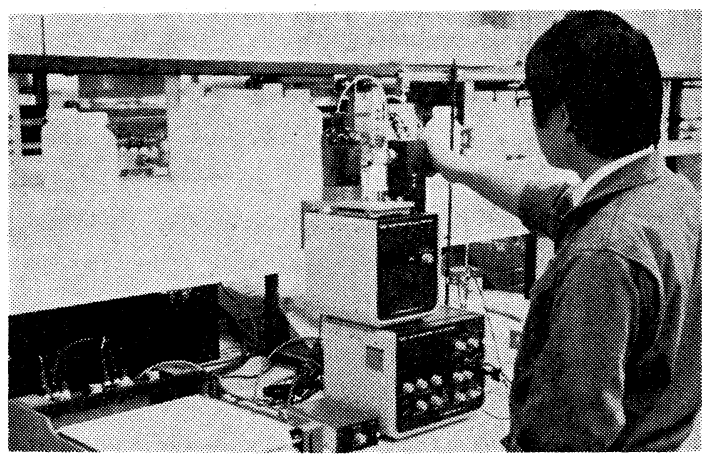

写真一6 コンクリート中に含まれる塩化物量の 分析 (電位差滴定法による)

現在，室内に抒ける試験方法の標準的手法が JIS 化 される動きにあり，「塩分を含んだコンクリート中にお ける補強用棒鋼の促進腐食試験方法 $\left.{ }^{12}\right\rfloor$ として JIS 案 (以下促進 JIS 案と略す) が示されている。更に，特殊

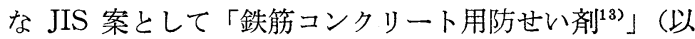
下防せい JIS 案と略す）がある。

本稿では, これら 2 種の JIS 原案を含め, 従来用い られてきた室内試験方法を紹介する。

室内試験に用いられる手法は，大きくわけて 2 種類に 分類できる。一つは腐食反応を促進させることにより， 腐食した結果を速く得る促進試験方法であり，他の一つ は腐食反応はそのままで, 反応要因を電気量に変換し, 高感度での測定を行う電気化学的試験法である。

\section{1 促進試験方法}

促進試験には次のような条件が必要とされる。

1）現実における腐食・防食機構に対応していること。

2）促進効果が高く，かつ促進率が定量化できること。

3）種々の試験目的に応じて適用できること。

4）簡便かつ容易に行えること。

しかし，その他の種々の条件も含めて，すべての条件 を完壁に満足させるような試験方法は，現在の段階では まだ確立されていない。 
ここで, 従来用いられてきた促進試験方法のうちで, 比較的上記の諸条件を満足するものとして, 乾湿繰返し 方法, 高温湿潤方法, オートクレーブ方法がある。

\section{（1）乾湿繰返し方法}

乾湿繰返し方法では, 通常, 高温湿潤と低温乾燥を繰 り返し行う。

高温湿潤環境下においては，腐食に必要な水を補給す るとともに，高温により腐食速度を促進する。しかし， コンクリートの含水量が大きくなると酸素の供給が遅れ

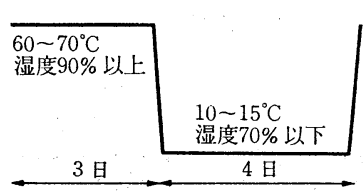

1 サイクル $=7$ 日

图一8 乾湿繰返し方法の一例 （標準として 20 サイ クル行ら) るため, 低温乾燥過程に おいて酸素の補給を行う とともに, 塩分を濃縮さ せる。

以上のような乾湿繰返 し方法は, 実際の腐食環 境に比較的近いと考えら れており，非常に有効な 促進方法である。促進

JIS 案における乾湿繰返し方法の例を図一8に示す。

\section{(2) 高温湿潤方法}

高温湿潤方法は, 温度を上昇させることによって腐食 速度が促進されることを利用したもので, 乾湿繰返し方 法での高温湿潤期閒に相当する。しかし， $80^{\circ} \mathrm{C}$ 以上に した場合には水分からの酸素の逸散が卓越し，かえって 腐食速度が低下することが知られており，通常は温度 $50 \sim 80^{\circ} \mathrm{C}$, 相対湿度 $90 \%$ 以上とされる。海砂中の塩分 など比較的低濃度の塩分では良い結果が得られにくい が, 海水などの高濃度の塩分ではその促進効果がよく知 られており ${ }^{14)}$ ，他の方法に比べて簡便である。

\section{（3）オートクレーブ方法}

オートクレーブ方法は, オートクレーブ容器を利用し 高温高圧蒸気によって腐食を促進させるものである。才 ートクレーブ容器の密閉度が高いため酸素が逸散せず,

3.1 (2) に述べたような高温時における腐食速度の減少

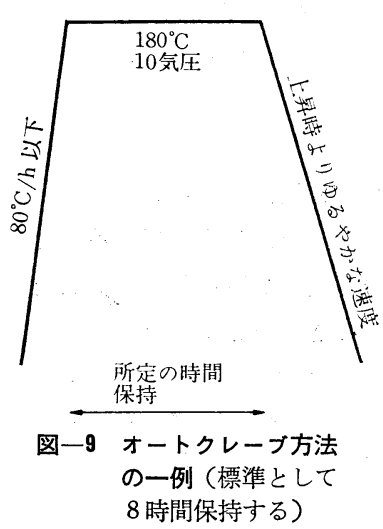
は生じない。このため, オートクレーブ方法によ る腐食促進効果は非常に 大きい(15),16)。

しかし，オートクレー ブ方法においては，コン クリートの内部組織に変 化を生じ，微小ひびわれ が生じたりする可能性が ある点に注意すべきであ る。

促進 JIS 案におけるオ
一トクレーブ方法の例を 図一9に示す。なお，防せい JIS 案におけけるオートクレーブ方法では, オートクレー ブを 2 回行い, その間に供試体を水中浸漬することにな っている。

\section{(4) 測定}

従来の研究によれば, 前述のどの促進方法を用いても 腐食量は少なく，腐食深さの測定は困難である。そのた め，発錆面積によって腐食量を表現することが多い。

しかし，腐食が非常に促進された場合，あるいは局部 的な深い腐食が生じた場合には, 腐食深さの測定も併せ て行い, 更に可能ならば, 腐食生成物の分析も行うこと が望ましい。

\section{2 電気化学的試験方法}

電気化学的試験方法としてよく用いられるものには, 自然電位法, 定電位分極試験あるいは抵抗分極法などが ある。ここで, 電気化学的手法では, 測定因子として電 位と電流しかなく，情報が非常に限られるため，目視観 察, 強度試験, 腐食減量の測定など他の測定も併用しな ければならない。

\section{(1) 自然電位法}

自然電位の経時変化測定は古くから行われている方法 である。コンクリート中あるいは $\mathrm{Ca}$ 飽和水溶液中の鋼 材の自然電位が貴の方向に移行すれば保護被膜が生じ防 食されるとされ，逆に卑の方向に移行すれば破壊され鋼 材の腐食が進行するとされる（図一10参照, 防せい JIS 案より)。

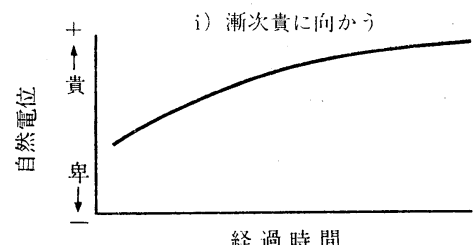

経過時間
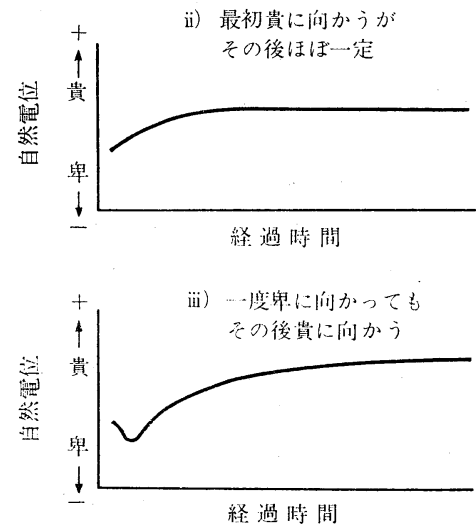

図一10 貴の方向に移行する場合の 自然電位-時間曲線の例 


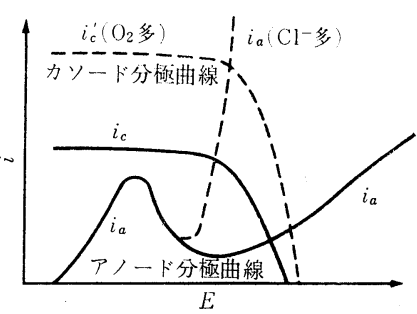

图ー11 アノード及びカソード分極曲線の概念図
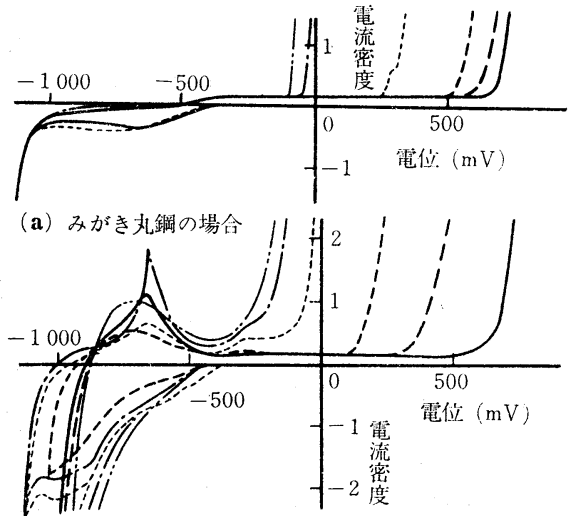

（b）黒皮付鉄筋の場合

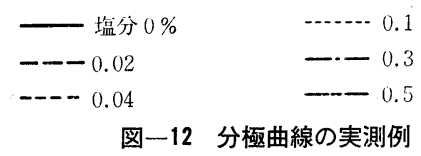

しかし，この方法は，今現実に生じている腐食反応が ぞのようなアノード反応, カソード反応によって生じて いるかがはっきりと分かっていなければその意味を解釈 できない。例えば図一11 に示すように, $\mathrm{Cl}$ イオンの増 加により不働態領域が減少し，アノード分極が小さくな り腐食速度が大きくなった場合においても，また酸素の 消費によりカソード分極が大きくなり腐食速度が小さく なった場合でも，同様に電位は卑に移行するからであ る。

ここで, Stratfull1 ${ }^{17}$ は種々の方法で鉄筋の自然電位の 分布を測定し, 腐食が生ずると方法に関係なく腐食電流 を生ずる電位勾配が生じ, 電位の絶対值には差があるも のの，すべて同様の等電位線図を描くことができ，腐食 位置が推定できることを報告している。このことは 2.2 に掠いて述べたように, 電位分布の測定が非常に重要で あることを示している。

\section{（2）定電位分極試験}

分極曲線の求め方としては，定電流法と定電位法があ る。定電流法とは電流を規制し，そのときの電位を測定 する方法であり，定電位法は逆に電位を規制し，そのと きの電流を測定する方法である。不働態被膜が生じて反 応が抑制されるような場合には定電位法が用いられ、コ ンクリート中，あるいは $\mathrm{Ca}$ 飽和溶液中では通常定電位
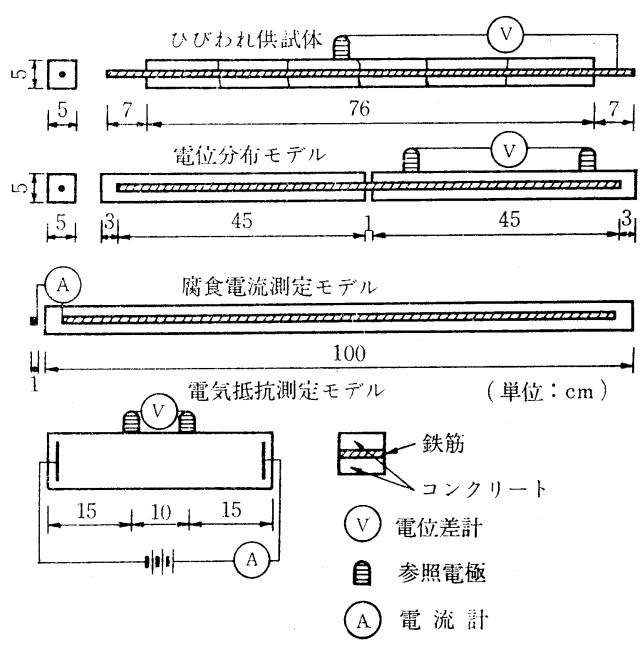

図一13 ひびわれ部腐食モデル供試体の例

法が用いられる。定電位分極曲線の例を図一12 に示す。 分極曲線からは不動態領域の変化, 孔食電位の推定, また場合によっては, ターフェル直線の外挿により腐食 電流の算出を行うことができる。

\section{(3) 抵抗分極法}

分極曲線から種々の情報を得る方法は，鋼材が自然腐 食電位から遠く隔たって分極されても電極表面の構造は 変わらないといら仮定を基としており，この仮定は必ず しも正しいとは限らない。

この問題を解消するためには, 自然腐食の状態からあ まり変化させずに測定することが望ましい。その方法と して分極抵抗法がある。腐食しつつある鋼材を外部電流 $i$ によって十分小さく分極 $\Delta E$ （約 $10 \mathrm{mV}$ 以下）させた 場合, 腐食電流 $I_{\text {corr }}$ と分極との関倸は次式で表され る。

$$
I_{\text {corr }}=K(i / \Delta E)
$$

$K$ は他の腐食測定法（主に腐食減量の重量測定）と 比較して求めればよい。分極抵抗法は短時間に腐食速度 を測定できるという利点がある。

分極抵抗法の実施例はまだあまり多くないが，良好な 結果を得たという報告がある ${ }^{199}$ 。

\section{3 そ 他}

その他, 種々の研究者によって, その研究の目的に応 じた様々のモデル供試体が用いられている。

例えば，コンクリート中の鉄筋の腐食機構としてマク ロセルがある。構造物に大きな被害をもたらすような腐 食機構はマクロセルである場合が多く, ミクロセル腐食 は実際上問題とならないことが多い100。

岡田ら ${ }^{20)}$ は，典型的なマクロセル腐食としてひびわれ を取り上げ，図一13に示すようなモデル供試体を用い て電位分布，マクロセル腐食電流，コンクリートの電気 


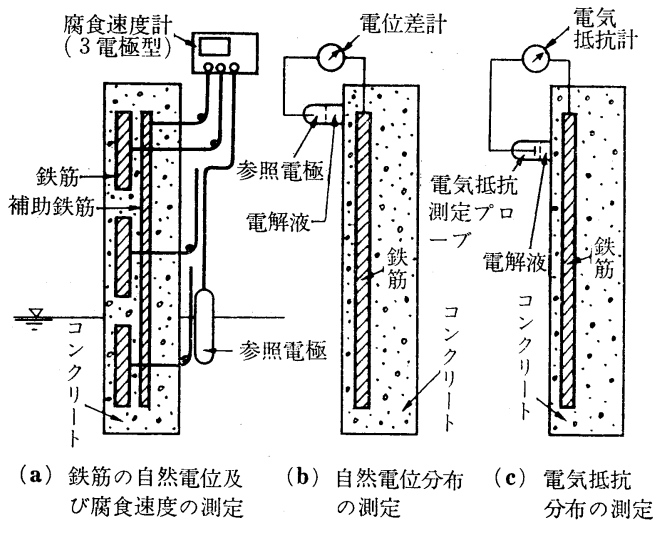

図一14 鉄筋の腐食挙動を測る電気化学測定手法

抵抗を測定しひびわれ部腐食機構を明らかにしてい る。

\section{4. 大規模な曝露試験の現状}

自然の環境条件下での，比較的現実に近い供試体曝露 試験は, 時間, 費用, 更には労力も要求され大変ではあ るが，構造物調查や室内試験だけでは得られない重要な 情報を得ることができる。曝露試験において用いられる 測定手法の例を図一14 に示す。

ここでは, 日本を含めて世界各国で行われている大規 模な曝露試験のうち 2 例を紹介し, 本文の締めくくりと したい。

建設省土木研究所では, 東京湾海上での曝露試験を昭 和 47 年より 10 年計画で進めている。これには写真一 7 に示すような鋼製曝露台船を海上に浮かべている。特 徵としては, 体系的な研究計画に基づいて, 基礎研究や 開発研究と密接に結びっけ, 室内で得られた成果を曝露 試験に反映させるとともに, 曝露試験結果を室内試験で 追試しより詳細に検討するという作業を繰り返している ことを挙げることができる。

また, U.S. Army Engineer Waterways Experiment Staion が中心となって行っている Treat Island におけ る曝露試験場（写真一8）に括いては，より幅広く，コ ンクリートそのものの耐久性を含めた R C， P C 構造の 大規模な曝露試験が行われている。

\section{参 考 文 献}

1）実松秀夫 : 鉄筋コンクリート床版の 損傷と疲労設計への アプローチ, pp. 5 26, 土木学会関西支部, 1977.7

2）日本コンクリート工学協会：コンクリートのひびわれ調 查・補修指針, 1980.5

3) ASTM C 876-77 : Half Cell Potentials of Reinforcing Steel in Concrete

4) 岡田 清, 宮川豊章ほか：第 2 回コンクリート工学年次 講演会講演論文集，pp. 5 8，1980.6

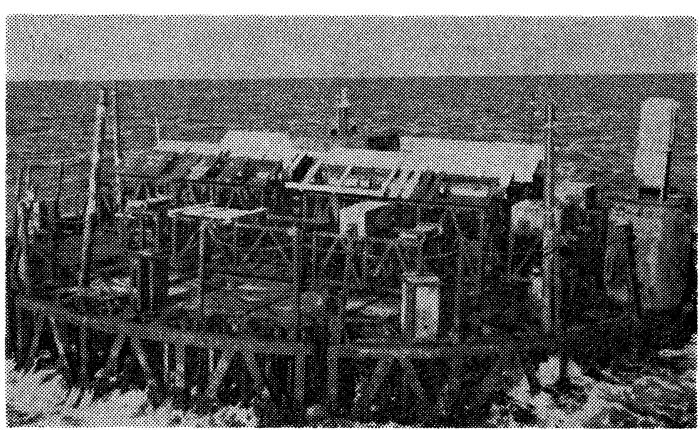

写真一7 建設省土木研究所による瀷露試験

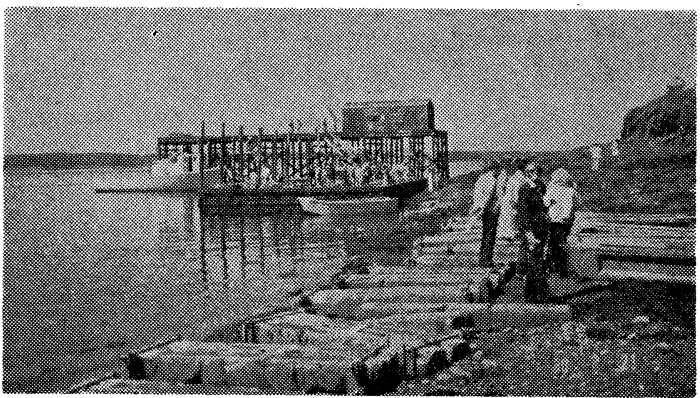

写真一8 アメリカ Treat Island における曝露試験場

5) K. Tuutti : ACI SP-65, pp. 223 236, 1980.8

6）蒔田 実, 片脇 清ほか：セメント技術年報, 第 33 巻, pp. $151 \sim 154,1979.12$

7) R.F. Stratfull et al : TRR, No. 539, pp. 50 59, 1975

8）能町 宏: 第 28 回日本材料学会コンクリート用混和剤委 員会資料, 1980.12 .5

9）岸谷孝一ほか：セメントコンクリート, No. 367 ,pp. 136 144, 1977.9

10）例えば, 森 芳徳, 片脇 清ほか：コンクリート構造物 のひびわれに関するシンポジウム発表報文集, pp. 133 〜 136, 1977.3

11) A. Goldstein et al : SE, Vol. 39, No. 10, pp. 332 $339,1961.10$

12）構造材料の安全性に関する標準化のための調查研究 ・ 研 究報告書, pp. $82 \sim 88,1980.3$

13）鉄筋コンクリート用防せい剤委員会資料， 1980.6

14）岡田 清, 宮川豊章ほか: 材料, No. 290, pp. 1110 $1116,1977.11$

15）小林一輔, 武若耕司 : 生産研究, Vol.30, No. 6, pp. 36 $\sim 37,1978.6$

16）武若耕司，小林一輔：土木学会第 33 回年次学術講演会概 要集 第 $\mathrm{V}$ 部, pp. $33 \sim 34,1978.9$

17） R.F. Strafull : HRR, No. 433, pp. 12 21, 1973

18）小林一輔ほか：土木学会第 35 回年次学術講演会講演概要 集 第 $\mathrm{V}$ 部, pp. 345 346, 1980.9

19）例えば，児玉和己ほか：鉄筋コンクリートにおける塩化 物の影響に関するシンポジウム発表報文集, pp. 41〜 44, 1975.3

20) K. Okada \& T. Miyagawa : ACI SP-65, pp. 237 $254,1980.8$

21）東京湾に抢ける暴露試験，土木研究所資料，1976

22）岡田 清, 宮川豊章: コンクリート工学, Vol. 17, No. 9, pp. $1 \sim 10,1979.9$

23）鉄筋コンクリート構造物の劣化度調查方法に関する提案, 土木研究所資料, 1980 